\title{
Association between celiac sprue and cryopyrin associated autoinflammatory disorders: a case report Marcus Shaker*1, Susan Edwards ${ }^{2}$, Henry Chionuma1, Eric Shamansky ${ }^{3}$ and Hal M Hoffman ${ }^{4}$
}

Address: ${ }^{1}$ Dartmouth-Hitchcock Medical Center Section of Pediatric Allergy and Clinical Immunology, Lebanon, NH, USA, ${ }^{2}$ Dartmouth-Hitchcock Medical Center Section of Pediatric Gastroenterology, Lebanon, NH, USA, ${ }^{3}$ Dartmouth-Hitchcock Medical Center Section of General Pediatrics, Lebanon, NH, USA and ${ }^{4}$ The University of California, San Diego School of Medicine, Division of Rheumatology, Allergy, and Immunology, La Jolla, CA, USA

Email: Marcus Shaker* - Marcus.S.Shaker@Hitchcock.ORG; Susan Edwards - Susan.T.Edwards@Hitchcock.ORG; Henry Chionuma - Henry.N.Chionuma@Dartmouth.edu; Eric Shamansky - Eric.M.Shamansky@Hitchcock.ORG; Hal M Hoffman - hahoffman@ucsd.edu

* Corresponding author

Published: 5 June 2007

Pediatric Rheumatology 2007, 5:12 doi:10.1 186/1546-0096-5-12

This article is available from: http://www.ped-rheum.com/content/5/I/I2

This is an Open Access article distributed under the terms of the Creative Commons Attribution License (http://creativecommons.org/licenses/by/2.0), which permits unrestricted use, distribution, and reproduction in any medium, provided the original work is properly cited.

\begin{abstract}
Cryopyrin-associated diseases may be characterized by rashes, fever, and sensorineural deafness, while celiac disease may present with symptoms of malabsorption and fatigue. Arthritis is seen in both conditions. We report a young child with histologically diagnosed celiac disease and a cryopyrinopathy.
\end{abstract}

\section{Background}

Cryopyrin-associated diseases (cryopyrinopathies) such as familial cold autoinflammatory syndrome (FCAS) and Muckle-Wells syndrome (MWS) (MIM \# 120100, 191900) result from mutations in the CIAS1 gene [1]. Celiac disease is a polygenic disease with a strong association to specific major histocompatibility Class II antigens. An association between cryopyrinopathies and celiac sprue has not been described.

\section{Case presentation}

We report a case of cryopyrinopathy and celiac disease in a 2 year-old Caucasian child. She presented with an 8 month history of almost daily fevers lasting 6-12 hours, occurring on average four to five times per week, with temperatures as high as $104^{\circ} \mathrm{F}$. She was irritable during fevers preferring to be carried when they occurred. Associated symptoms included loose stools, periodic evanescent maculopapular rashes, episodic abdominal discomfort,
Received: 25 January 2007

Accepted: 5 June 2007 
Abdomen was soft without organomegaly or masses. There was no clubbing or active rash, gait and station were normal. Musculoskeletal examination was normal with full range of motion of the shoulders, elbows, wrists, hips, knees, and ankles without effusions.

Evaluations included a normal complete blood count, immunoglobulins, and erythrocyte sedimentation rate during periods of fever. Urine cultures were negative, abdominal ultrasound was normal, and no infectious etiologies were identified (Table 1). Ophthalmology and audiology examinations were normal. Evaluation for celiac disease included an IgA anti-tissue transglutaminase antibody that was detected at 78 units per $\mathrm{mL}$ (normal < 3.9). Endoscopy was performed and a duodenal biopsy demonstrated marked villous atrophy with crypt hyperplasia and increased intraepithelial lymphocytes consistent with a diagnosis of celiac sprue. Disacharidase activity was low and consistent with untreated celiac disease. A gluten-free diet was associated with modest improvement in gastrointestinal symptoms but the fevers, rash, and arthralgias continued largely unabated. Testing for cryopyrinopathy and familial fever syndromes was per-

Table I: Evaluation of a toddler with recurrent fever.

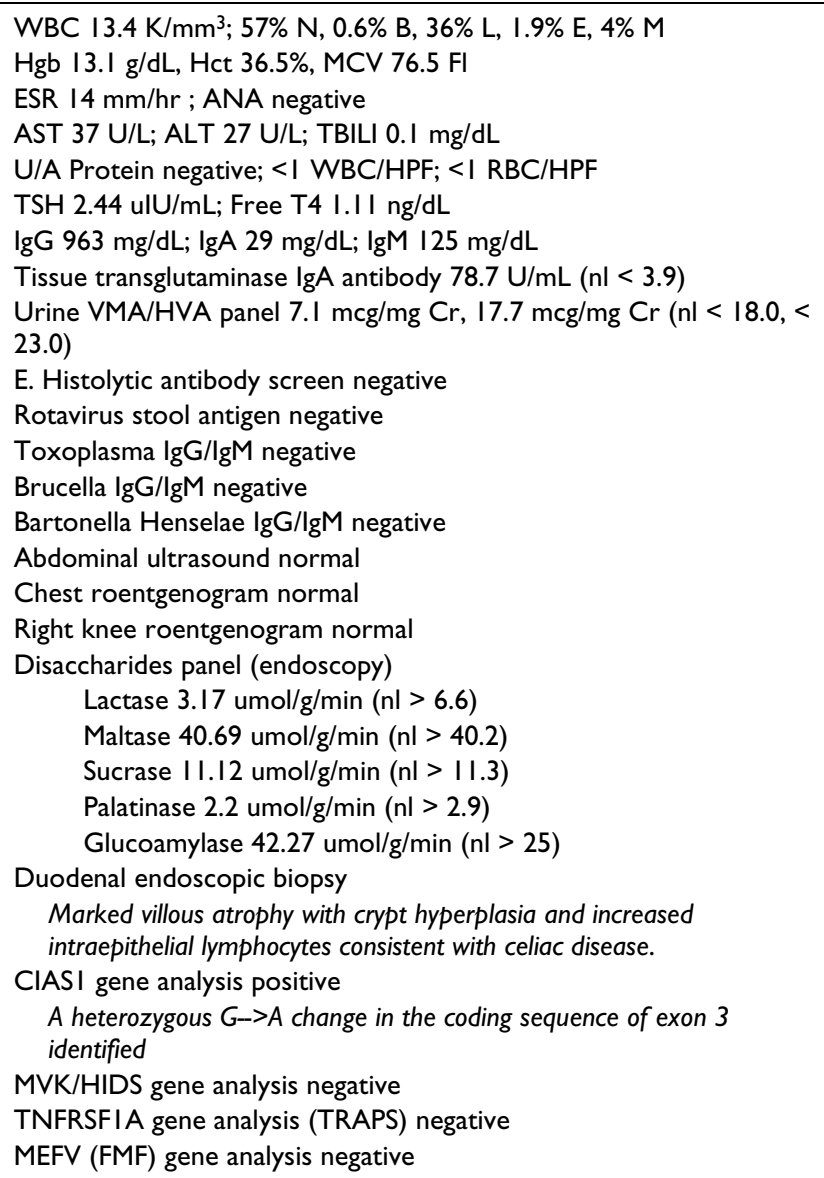

formed and a disease associated CIAS1 mutation was detected $[1,2]$. A heterozygous $G>A$ change in the coding sequence of exon 3 of CIAS1 causing replacement of the normal Valine codon (GTG) with a Methionine codon (ATG) at amino acid position 200 (Val200Met) was identified. Daily treatment with Anakinra $30 \mathrm{mg}$ was associated with resolution of the rash, however arthralgia and fevers have continued.

\section{Discussion}

This is the first report to our knowledge of a cryopyrinopathy in a patient with celiac disease. The Val200Met change identified in this patient has been described as a nonpenetrant mutation since it has been identified in several patients with FCAS, MWS, non-specific inflammatory diseases, and normal controls. Given the ancestry of this patient it is possible that the co-occurrence of these diseases is coincidental; however, an interaction between cryopyrin, interleukin- $1 \beta$, and gliadin reactive $\mathrm{T}$ cells also seems plausible.

Approximately 50 CIAS1 mutations have been reported [3]. It has been proposed that these mutations result in a gain of function for cryopyrin resulting in increased caspase- 1 activation and interleukin- $1 \beta$ release. This is supported by the response of FCAS and MWS patients to IL-1 targeted therapy $[4,5]$. However, a role for cryopyrin in the regulation of apoptosis and in the interplay between innate and adaptive immunity has also been hypothesized $[6,7]$. Celiac disease results from a loss of T cell tolerance to gliadin epitopes encountered in gut mucosal lymphoid tissue. The pathophysiologic connection between these disorders may relate to regulation of tolerance through innate immune responses or apoptotic pathways $[8,9]$. Because cryopyrin plays an important role in the production of active interleukin- $1 \beta$, abnormal cryopyrin responses may promote a local inflammatory milieu that could contribute to the generation of gliadin reactive $\mathrm{T}$ cells.

This case highlights the spectrum of clinical presentations associated with autoinflammatory conditions. It is a reminder that although a single process is usually responsible for signs and symptoms during childhood illnesses, multiple diseases can from time to time occur in the same patient and challenge Ockham's Razor. Further studies to explore the frequency of association between these disorders may be warranted.

\section{Acknowledgements}

No financial support was received for this report.

\section{References}

I. Hoffman HM, Mueller JL, Broide DH, Wanderer AA, Kolodner RD: Mutation of a new gene encoding a putative pyrin-like protein causes familial cold autoinflammatory syndrome and Muckle-Wells syndrome. Nat Genet 200I, 29(3):30I-305. 
2. Aganna E, Martinon F, Hawkins PN, Ross JB, Swan DC, Booth DR, Lachmann HJ, Bybee A, Gaudet R, Woo P, et al: Association of mutations in the NALP3/CIASI/PYPAFI gene with a broad phenotype including recurrent fever, cold sensitivity, sensorineural deafness, and AA amyloidosis. Arthritis Rheum 2002, 46(9):2445-2452.

3. Infevers [http://fmf.igh.cnrs.fr/infevers/]. Last Accessed 10/7/06.

4. Hawkins PN, Lachmann HJ, Aganna E, McDermott MF: Spectrum of clinical features in Muckle-Wells syndrome and response to anakinra. Arthritis Rheum 2004, 50(2):607-612.

5. Hoffman HM, Rosengren S, Boyle DL, Cho JY, Nayar J, Mueller JL, Anderson JP, Wanderer AA, Firestein GS: Prevention of coldassociated acute inflammation in familial cold autoinflammatory syndrome by interleukin-I receptor antagonist. Lancet 2004, 364(9447): I779- 1785.

6. Sutterwala FS, Ogura Y, Szczepanik M, Lara-Tejero M, Lichtenberger GS, Grant EP, Bertin J, Coyle AJ, Galan JE, Askenase PW, et al:: Critical role for NALP3/CIASI/Cryopyrin in innate and adaptive immunity through its regulation of caspase-I. Immunity 2006, 24(3):3I7-327.

7. Ting JP, Kastner DL, Hoffman HM: CATERPILLERs, pyrin and hereditary immunological disorders. Nat Rev Immunol 2006, 6(3): $183-195$

8. Matysiak-Budnik T, Candalh C, Dugave C, Namane A, Cellier C, CerfBensussan N, Heyman M: Alterations of the intestinal transport and processing of gliadin peptides in celiac disease. Gastroenterology 2003, I 25(3):696-707.

9. Stepniak D, Koning F: Celiac disease - sandwiched between innate and adaptive immunity. Hum Immunol 2006, 67(6):460-468.

Publish with Bio Med Central and every scientist can read your work free of charge

"BioMed Central will be the most significant development for disseminating the results of biomedical research in our lifetime. "

Sir Paul Nurse, Cancer Research UK

Your research papers will be:

- available free of charge to the entire biomedical community

- peer reviewed and published immediately upon acceptance

- cited in PubMed and archived on PubMed Central

- yours - you keep the copyright 